\title{
Ovarian carcinoma presenting as pyrexia of unknown origin
}

\author{
P.M. Schofield*, B.A. Kirsop, P. Reginald and M. Harington \\ St Charles' Hospital, Exmoor Street, London W10, UK.
}

\begin{abstract}
Summary: A patient with a poorly differentiated clear cell adenocarcinoma of the ovary presenting as pyrexia of unknown origin is reported. Following resection of the tumour, her pyrexia resolved completely.
\end{abstract}

\section{Introduction}

In a recent review, neoplastic disease accounted for over $30 \%$ of pyrexias of unknown origin (PUO) (Larson et al., 1982). We report here a patient with ovarian carcinoma presenting as PUO. A search of the world literature over the past twenty years revealed only one such previously reported case (Maestu et al., 1979).

\section{Case report}

A fifty-one year old woman with longstanding rheumatic aortic valve disease presented in May 1983 with a two month history of general malaise, loss of weight, dry cough and night sweats. More recently she had noticed some low back pain. On examination she had signs of mixed aortic valve disease but no stigmata of infective endocarditis.

\section{Investigations}

Haemoglobin $11.0 \mathrm{~g} / \mathrm{dl}$, white cell count $13.9 \times 10^{9} / 1$ $(87 \%$ neutrophils) and ESR $60 \mathrm{~mm} / \mathrm{h}$. Her chest X-ray showed cardiomegaly but was otherwise normal, and initial blood cultures were sterile. During the next week she had an intermittent pyrexia, but several further blood cultures were sterile and an echocardiograph revealed no evidence of vegetations on her heart valves. A presumptive diagnosis of infective endocarditis was made. As the patient gave a history of penicillin sensitivity she was treated with gentamicin and cephazolin.

The patient remained pyrexial and her back pain

\footnotetext{
P.M. Schofield, M.R.C.P.; B.A. Kirsop, M.B., B.S.; P. Reginald, M.R.C.O.G.; M. Harington, F.R.C.P.

* Present address: St Mary's Hospital, Praed Street, London W.2

Correspondence: P.M. Schofield

Accepted: 3 January 1984
}

worsened. Four weeks after admission her haemoglobin was $9.9 \mathrm{~g} / \mathrm{dl}$, white cell count $22.9 \times$ $10^{9} / 1$ (87\% neutrophils) and ESR $123 \mathrm{~mm} / \mathrm{h}$. Serological tests for various infective agents were negative.

A gynaecological opinion was sought; vaginal examination revealed fullness-and tenderness in the left fornix and an ultrasound scan showed a mass lying posteriorly to the bladder. At laparoscopy the patient was found to have a left ovarian mass with malignant cells present in peritoneal washings. Subsequently she had a hysterectomy, bilateral salpingo-oophorectomy and omentectomy. The tumour, which was $8 \mathrm{~cm}$ in diameter, was a poorly differentiated clear cell adenocarcinoma of the left ovary. This had penetrated the capsule but there was no macroscopic evidence of spread to other structures, including the liver. Following resection of the tumour her pyrexia resolved completely within $48 \mathrm{~h}$, and she has remained apyrexial since.

\section{Discussion}

This case illustrates the difficulties encountered in diagnosis when a pyrexial illness presents in a patient with known cardiac valve disease. A clinical diagnosis of infective endocarditis may have to be made and appropriate antibiotic treatment instituted in the absence of the isolation of any micro-organisms from blood culture; indeed it has been suggested that up to $20 \%$ of cases of infective endocarditis may have repeatedly negative blood cultures, the usual cause being recent treatment with antibiotics (Oakley, 1980).

In the recent series of Larson et al. (1982) malignant disease rather than infection was found to be the commonest disease category causing PUO. Neoplasms involving the reticuloendothelial system, including lymphomas and leukaemias, accounted for two-thirds of cases. The other one-third were patients 
with solid tumours, usually of intra-abdominal origin, particularly renal and hepatic carcinomas.

We report here a patient with a poorly differentiated clear cell adenocarcinoma of the ovary presenting as PUO. We have only been able to trace one similar reported case (Maestu et al., 1979); in that patient the histological diagnosis was of ovarian cystadenocarcinoma and, as in our patient, the pyrexia resolved completely within $48 \mathrm{~h}$ of removal of the tumour.

\section{References}

LARSON, E.B., FEATHERSTONE, H.J. \& PETERSDORF, R.G. (1982). Fever of undetermined origin: diagnosis and follow-up of 105 cases, 1970-80. Medicine (Baltimore), 61, 269.

MAESTU, R.P., BUZON, L.M., FRAILE, L., GUERRERO, A., ALONSO, J.J., ALAMO, A., VIDAL, J.J., MASA, C. \&

\section{Acknowledgements}

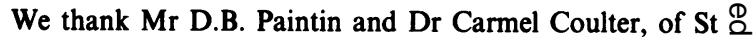
Mary's Hospital, London W2 for their advice in the man- $C$. agement of this patient, and to Mrs S.B. Kent for typing the $\vec{F}$ manuscript.

FRIEYRO, J.E. (1979). Carcinoma de ovario como causa de fiebre de origen desconocido. A proposito de un caso. Revista Clinica Espanola, 153, 65.

OAKLEY, C.M. (1980). Infective endocarditis. British Journal of Hospital Medicine, 24, 232. 